\title{
Effect of the Chemical Homogeneity of a Quenched and Tempered C-Mn Steel Pipe on the Mechanical Properties and Phase Transformations
}

\author{
Ana Paula da Silva Lima *iD, Geraldo Lúcio de Faria ${ }^{a}$, Vicente Braz da Trindade Filho \\ Luiz, Cláudio Cândido ${ }^{a}$ \\ ${ }^{a}$ Rede Temática em Engenharia de Materiais - REDEMAT, Universidade Federal de Ouro Preto, Ouro \\ Preto, $M G$, Brasil
}

Received: October 19, 2018; Revised: March 26, 2019; Accepted: April 29, 2019

\begin{abstract}
Seamless steel pipes for application in the oil and gas industries are manufactured from quenched and tempered steel. Aiming to meet the required characteristics, it is necessary that the microstructure and the mechanical properties are homogeneous along the wall thickness of the pipes, which is even more critical for thick wall pipes. Considering the seamless steel pipe manufacturing process, any chemical segregation along the thickness could affect the phase transformation kinetics during heat treatments and, consequently, microstructure and mechanical properties. In this context, this pioneer work when evaluating the effect of the chemical homogeneity of a seamless pipe on the mechanical properties and phase transformations. The studied pipe was manufactured by a C-Mn steel designed for oil and gas industry applications. Two regions of the pipe wall were analyzed - a region close to the inner surface and another near the outer surface. The steel was subjected to quenching and tempering heat treatments. Scanning electron and optical microscopy techniques were used to characterize the resultant microstructures. Microhardness and Charpy impact tests were performed aiming to analyze the pipe mechanical behavior in the studied regions. In addition, dilatometric tests were performed in order to determine the continuous cooling transformation diagrams of these regions.
\end{abstract}

Keywords: $C-M n$ steel, seamless pipes, chemical segregation, mechanical properties, CCT diagram.

\section{Introduction}

Steel semi-products, such as slabs and billets, due to the solidification conditions, inevitably have some degree of chemical segregation in their central portion ${ }^{1-3}$, which gradually reaches significant degrees with the increasing of ingot size ${ }^{3,4}$. This heterogeneity can be transmitted to the final steel product resulting in small microstructural changes as well as discontinuities that may eventually influence the local mechanical properties ${ }^{1}$.

The occurrence of this phenomenon has become relevant in the seamless pipe manufacturing process because, recently, there are applications that require pipes with higher diameters and thicker walls ${ }^{5,6}$. These demands stem from the need to improve the efficiency of the oil and natural gas transportation in deeper waters for longer distances, subjecting pipelines to high-pressure conditions ${ }^{5-9}$.

Normally, seamless pipes are subjected to quenching and tempering heat treatments in order to obtain the required properties ${ }^{10,11}$. Accordingly, the chemical gradient along the pipe thickness may cause variation of the local hardenability during these heat treatments, making it more difficult to ensure a uniform microstructure along the thickness. This fact can lead to a heterogeneous mechanical behavior, mainly in relation to toughness and fatigue, compromising the reliability and operational safety of the pipe.

"e-mail: limapsana@gmail.com.
In this context, this work pioneering sought to evaluate the effect of the chemical homogeneity along the thick-walled seamless C-Mn steel pipe, analyzing whether eventual differences in chemical composition influence the continuous cooling transformation (CCT) diagrams, besides to verifying how these changes affect the microstructures, after the quenching and tempering heat treatments, and the mechanical properties. To perform this work, two regions of the pipe wall (near the inner and outer surfaces) were analyzed.

\section{Materials and Methods}

The studied C-Mn steel was provided as seamless steel pipe with nominal outside diameter measuring $273 \mathrm{~mm}$ and wall thickness measuring $30 \mathrm{~mm}$. This steel complies with the chemical composition specifications required by API 5L Standard ${ }^{12}$ for grade X80, with the maximum concentrations (wt. $\%$ ) for each element of $0.18 \% \mathrm{C} ; 1.90 \%$ $\mathrm{Mn} ; 0.15 \% \mathrm{Nb}+\mathrm{Ti}+\mathrm{V} ; 0.45 \% \mathrm{Si} ; 0.015 \% \mathrm{~S} ; 0.025 \% \mathrm{P} ; 0.50 \% \mathrm{Cu}$; $0.50 \% \mathrm{Cr} ; 1.00 \% \mathrm{Ni} ; 0.50 \% \mathrm{Mo}$ and $0.004 \% \mathrm{~B}$.

The chemical analyses were performed by optical emission spectrometry technique in two regions (Figure 1) of the cross section of the pipe wall: near the outer surface (Position 1) and close to the inner surface (Position 2).

In order to experimentally determine the austenitizing critical temperatures $\mathrm{Ac}_{1}$ and $\mathrm{Ac}_{3}$, as well as the steel 


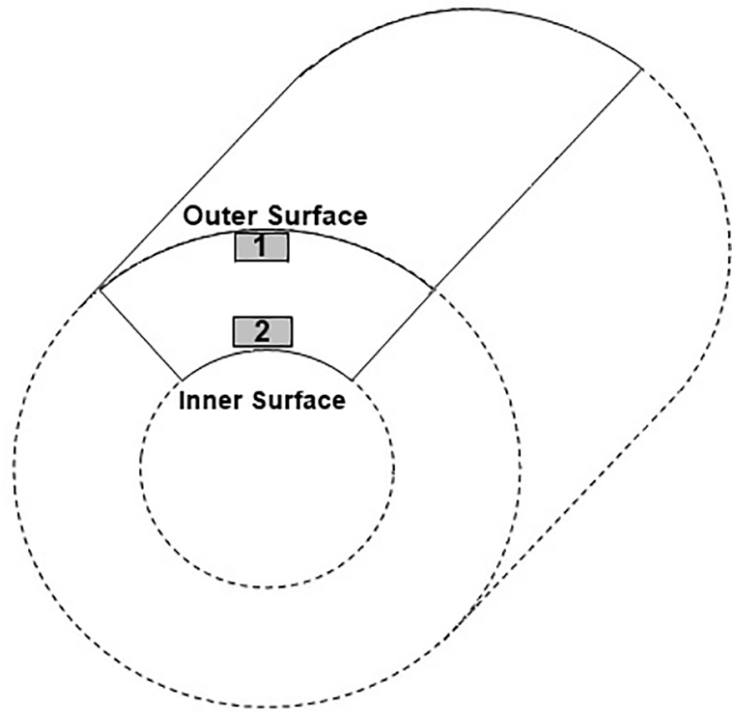

Figure 1. Schematic figure exemplifying the regions of the pipe wall studied in this work.

Continuous Cooling Transformation (CCT) diagram, dilatometric experiments were carried out. These tests were performed in a RITA L78 quenching dilatometer, using type $\mathrm{K}$ thermocouples to measure temperature. Twelve solid cylinders with a diameter of $3 \mathrm{~mm}$ and a length of $10 \mathrm{~mm}$ were machined from each studied region and they were heated to $920^{\circ} \mathrm{C}$ with a constant heating rate of $3^{\circ} \mathrm{C} / \mathrm{s}$. The samples remained at $920^{\circ} \mathrm{C}$ for $180 \mathrm{~s}$ and were then cooled down to room temperature, under continuous Helium gas flow with different cooling rates: $0,5^{\circ} \mathrm{C} / \mathrm{s}, 1^{\circ} \mathrm{C} / \mathrm{s}, 2^{\circ} \mathrm{C} / \mathrm{s}, 3^{\circ} \mathrm{C} / \mathrm{s}, 5^{\circ} \mathrm{C} / \mathrm{s}$, $7^{\circ} \mathrm{C} / \mathrm{s}, 10^{\circ} \mathrm{C} / \mathrm{s}, 15^{\circ} \mathrm{C} / \mathrm{s}, 20^{\circ} \mathrm{C} / \mathrm{s}, 25^{\circ} \mathrm{C} / \mathrm{s}, 50^{\circ} \mathrm{C} / \mathrm{s}$ and $100^{\circ} \mathrm{C} / \mathrm{s}$. The samples which were submitted to cooling rates of $2^{\circ} \mathrm{C} / \mathrm{s}$, $7^{\circ} \mathrm{C} / \mathrm{s}, 20^{\circ} \mathrm{C} / \mathrm{s}$ and $100^{\circ} \mathrm{C} / \mathrm{s}$ were characterized after etched with Nital 2\% using light optical (OM, Pantec) and scanning electron (SEM, Vega3 Tescan) microscopy techniques. Finally, all the specimens were submitted to the Vickers microhardness test ${ }^{13}$, using a $200 \mathrm{gf}$ load and $5 \mathrm{~s}$ dwell time using a Pantec microhardness tester. The average values of ten measurements are reported.

The dilatometric curves were obtained and the $\mathrm{Ac}_{1}$, $\mathrm{Ac}_{3}, \mathrm{Ar}_{1}$ and $\mathrm{Ar}_{3}$ temperatures were measured using the minimal linear deviation method concomitantly with the first derivative method ${ }^{14-19}$. On heating, the $\mathrm{Ac}_{1}$ and $\mathrm{Ac}_{3}$ temperatures were measured in all the austenitization curves being 12 specimens from each region. From the obtained results, the $\mathrm{Ac}_{1}$ and $\mathrm{Ac}_{3}$ average values were calculated by arithmetic mean. In the study of austenitizing kinetics, the lever rule was applied to estimate the volume fraction of austenite from dilatometric data ${ }^{14-16}$ and then the JohnsonMehl-Avrami-Kolmogorov, or JMAK, equation ${ }^{20,21}$ was employed (Equation 1). This equation is generally used to model transformations under isothermal conditions, however many authors have applied this equation to study the transformation kinetics under nonisothermal conditions obtaining satisfactory results ${ }^{14-16,18,22,23}$.

$$
Y=1-\exp \left(-k \cdot t^{n}\right)
$$

where $k$ and $n$ are kinetic parameters, $Y$ is the austenite volume fraction, and $t$ is the transformation time.

In addition, the C-Mn steel was subjected to quenching and tempering heat treatments, outlined in Figure 2. Specimens for the microstructural analysis and Vickers microhardness tests were sampled from the pipe before the heat treatments (as-rolled sample) and after each stage of the heat treatments, the cross section was also analyzed in all cases. Microstructural analysis were performed by $\mathrm{OM}$ and SEM techniques. The specimens were mechanically polished ${ }^{24}$ and etched by a Nital $2 \%$ etchant. Besides, samples after the quenching treatment were taken to evaluate the average prior austenitic grain size of each position - using the Teepol etchant $(2,4 \mathrm{gm}$ dry picric acid in $100 \mathrm{ml}$ distilled water, $2 \mathrm{ml}$ concentrated hydrochloric acid and few drops of neutral detergent) and using the intercepts method ${ }^{25}$ - and for qualitative analysis of the martensite-austenite (MA) constituent presence - using the LePera etchant ${ }^{26}$ (equal portions of solutions: (A) $1 \%$ aqueous sodium metabisulfite; and (B) 4gm dry picric acid in $100 \mathrm{ml}$ ethanol). The Vickers microhardness tests ${ }^{13}$ were performed and an average of twelve microhardness measurements was reported for each analyzed region.

Charpy impact tests were performed at $-30^{\circ} \mathrm{C}$ and $-60^{\circ} \mathrm{C}$ in an Instron machine of 407J capacity. The subsize standard specimens (size, $10 \times 5 \times 55 \mathrm{~mm}$ ) ${ }^{27}$ were made with notches in the longitudinal direction of the pipe. The samples were machined from the two regions of the pipe (position 1 and position 2) after the quenching and tempering heat treatments.

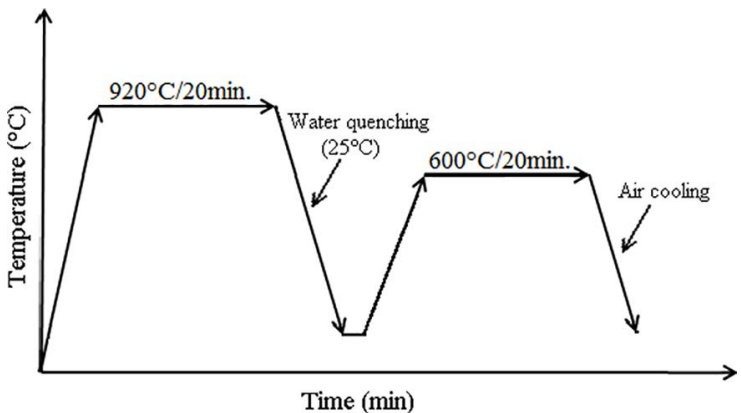

Figure 2. Schematic representation of the heat treatments used in this work. 


\section{Results and Discussion}

\subsection{Chemical analysis}

Table 1 presents the steel chemical composition in the two analyzed regions highlighting the percentage changes in the contents of the elements in the position 2 sample in relation to the position 1 sample. It is observed that there is a trend of chemical segregation from the outermost part to the innermost part of the pipe wall, especially $\mathrm{C}, \mathrm{Mn}, \mathrm{Si}$, $\mathrm{Nb}$ and $\mathrm{B}$. These differences in chemical composition may be related to the effects of chemical segregation from bar solidification, where chemical segregation tends to occur in the central region. In the seamless pipe manufacturing process, during the bar strain, segregation in the central region of the billet moves to the innermost part of the pipe wall.

\subsection{Dilatometry}

Figure 3 shows, on a dilatation curve of a dilatometry specimen during heating $\left(\right.$ at $\left.3{ }^{\circ} \mathrm{C} / \mathrm{s}\right)$, the application of the lever rule, and the minimal linear deviation and first derivative methodologies to determine critical temperatures. The critical temperatures $\mathrm{Ac}_{1}$ and $\mathrm{Ac}_{3}$ are indicated in the figure.

The average temperatures $\mathrm{Ac}_{1}$ and $\mathrm{Ac}_{3}$ measured for the two positions studied are presented in Table 2. It can be observed that there is no significant difference for the measured $\mathrm{Ac}_{3}$ temperature in both positions, but the $\mathrm{Ac}_{1}$ temperature of the position 1 is higher than the other. This small change in $\mathrm{Ac}_{1}$ temperature, although within the experimental deviation of the technique, is consistent with the differences in chemical composition presented in Table 1. Comparing position 2 with position 1, it was observed an increase in the contents of $\mathrm{C}, \mathrm{Mn}$ and $\mathrm{B}$, which may contribute to the decrease of the critical temperatures ${ }^{28-30}$, as well as the $\mathrm{Si}$ content which has a strong effect on the increase of these temperatures ${ }^{31-33}$. However, a more pronounced effect of the elements $\mathrm{C}, \mathrm{Mn}$ and $\mathrm{B}$ than the effect of $\mathrm{Si}$ is observed, resulting in a decrease in the $\mathrm{Ac}_{1}$ temperature.

$\mathrm{The}_{\mathrm{Ac}}$ temperature is strongly coupled to the nucleation stage of the new phase, which is a stage of transformation that depends greatly on the thermodynamic system and therefore on the chemical composition. In view of this, the small chemical variations could be affecting the local energy

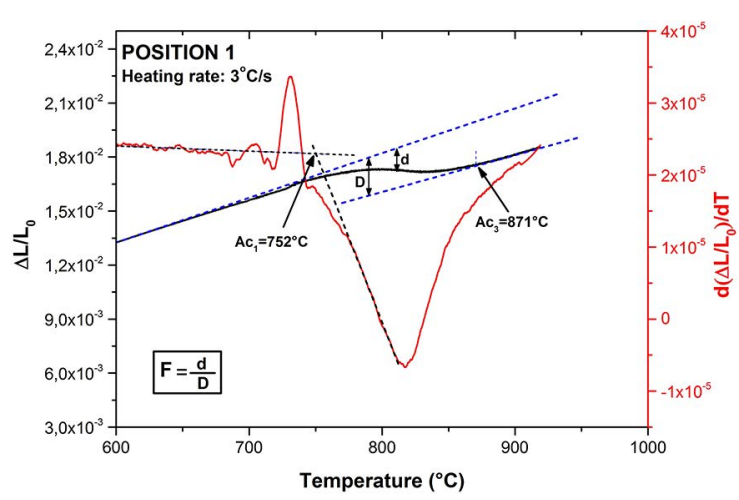

Figure 3. Dilatation curve of a dilatometry specimen for the heating rate of $3^{\circ} \mathrm{C} / \mathrm{s}$. F is the fraction of austenite determined by lever rule.

Table 2. Austenitizing critical temperatures of the C-Mn steel.

\begin{tabular}{ccc}
\hline & POSITION & TEMPERATURE $\left({ }^{\circ} \mathrm{C}\right)$ \\
\hline $\mathrm{Ac}_{1}$ & 1 & $756 \pm 7$ \\
& 2 & $735 \pm 8$ \\
$\mathrm{Ac}_{3}$ & 1 & $871 \pm 6$ \\
& 2 & $873 \pm 9$
\end{tabular}

Position 1: outer region; Position 2: inner region.

and changing the austenite nucleation stage. However, these changes would not be significantly affecting the austenite growth stage, thus justifying a lower influence on the $\mathrm{Ac}_{3}$ temperature.

The austenite volume fraction as a function of time was determined and, by non-linear fitting to the JMAK equation (Equation 1), the average kinetic parameters $\mathrm{n}$ and $\mathrm{k}$ were obtained and they are presented in Figure 4 for the two studied positions. The $\mathrm{n}$ exponent indicates which site is preferential to the nucleation of the new phase. For $n=2$ (value close to that found for the two positions) the preferential nucleation site is at the grains edges as pointed out by Cahn $(1956)^{34}$. On the other hand, the $\mathrm{k}$ constant is related to the transformation rate of phases ${ }^{16,35}$, nucleation and growth, and the value obtained for position 1 and position 2 was $1.79 \times 10^{-3}$ and $7.64 \times 10^{-4}$, respectively. Figure 4 shows that the austenitic transformation rate is higher for position 1 , which may be related to a lower concentration of chemical elements compared with the other position. Since the austenitizing kinetics is controlled by carbon diffusion ${ }^{36,37}$,

Table 1. Differences in chemical composition of position 2 relatively to position 1 .

\begin{tabular}{llllllllllllll}
\hline Element & $\mathrm{C}$ & $\mathrm{Mn}$ & $\mathrm{P}$ & $\mathrm{S}$ & $\mathrm{Si}$ & $\mathrm{Ni}$ & $\mathrm{Cr}$ & $\mathrm{Mo}$ & $\mathrm{Al}$ & $\mathrm{V}$ & $\mathrm{Nb}$ & $\mathrm{B}$ & $\mathrm{CE} \mathrm{Pcm}$ \\
\hline $\begin{array}{l}\text { Differences } \\
\text { in chemical } \\
\text { composition (\%) }\end{array}$ & 6.9 & 2.2 & 16.7 & 9.1 & 4.3 & 1.3 & 0.8 & 1.2 & 3.4 & 2.4 & 11.0 & 25.0 & 5.7 \\
\hline$C E_{P c m}=C+\frac{S i}{30}+\frac{M n}{20}+\frac{C u}{20}+\frac{N i}{60}+\frac{C r}{20}+\frac{M o}{15}+\frac{V}{10}+5 B^{10}$ & & & & & & & & & & & & &
\end{tabular}




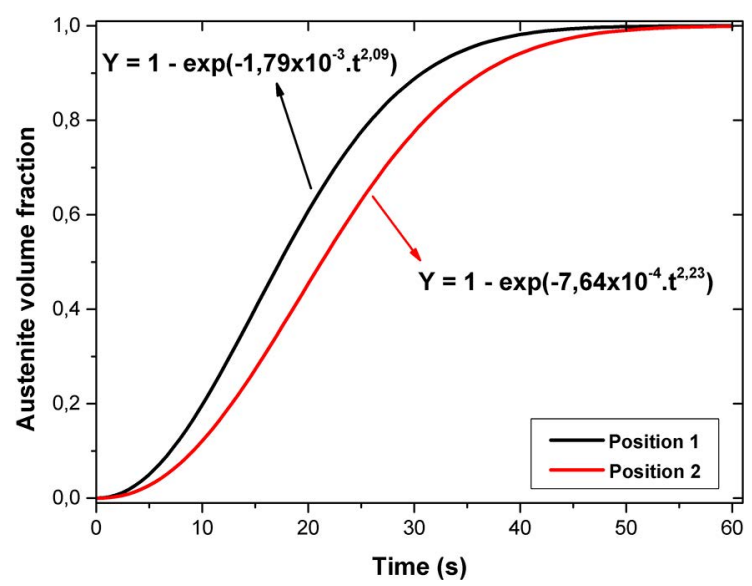

Figure 4. Austenite volume fraction as function of the time for position 1 and position 2 with the values of $\mathrm{n}$ and $\mathrm{k}$.

with the lowest concentration of alloying elements there is less difficulty for the carbon diffusion which leads to the increase of the transformation rate.

Figure 5 shows divers optical micrographs of the samples cooled at different cooling rates $\left(2,7,20\right.$, and $\left.100^{\circ} \mathrm{C} / \mathrm{s}\right)$, for the $\mathrm{C}$-Mn steel in the both regions. Depending on the cooling rate, the transformation microstructures vary broadly. There is a gradual change in the low cooling rate microconstituents and phases such as polygonal ferrite $(\mathrm{PF})$, perlite $(\mathrm{P})$, and degenerate perlite $\left(\mathrm{P}^{\prime}\right)\left(2{ }^{\circ} \mathrm{C} / \mathrm{s}\right)$ (Figures $5(\mathrm{a})$ and $\left.(\mathrm{e})\right)$ to fast cooling rate such as bainite $(\mathrm{B})$ and martensite $(\mathrm{M})$ (higher rates than $50^{\circ} \mathrm{C} / \mathrm{s}$ ) (Figures $5(\mathrm{~d})$ and (h)). A change through the microstructures composed of quasipolygonal ferrite $(\mathrm{QF})$, granular ferrite (GF) and bainitic ferrite (BF) (Figures 5(b), (c), (f), and (g)) can be observed for intermediate cooling rates (from 7 to $20^{\circ} \mathrm{C} / \mathrm{s}$ ).

SEM characterization was also performed for a better microstructural features observation. Figures 6(a)-(d) show the micrographs corresponding to position 2 for 2 , 7,20 and $100^{\circ} \mathrm{C} / \mathrm{s}$ cooling rates, respectively. In Figures 6(e)-(h), more detailed micrographs of these phases are shown. At the rate of $2^{\circ} \mathrm{C} / \mathrm{s}$, the ferrite forms mainly as $\mathrm{PF}$ and the $\mathrm{P}$ and $\mathrm{P}^{\prime}$ are detected (Figures 6(a) and (e)). At the rate of $7^{\circ} \mathrm{C} / \mathrm{s}$, the ferrite forms mostly as $\mathrm{QF}$, with a small fraction of GF and BF (Figures 6(b) and (f)). As a result of the increase in the cooling rate, the bainite undergoes perceptible morphology changes leading to a transition from $\mathrm{GF}$ to $\mathrm{BF}$ microstructures (cooling range between 20 and $50^{\circ} \mathrm{C} / \mathrm{s}$ ) (Figures $6(\mathrm{c})$ and $(\mathrm{g})$ ). At the rate of $100^{\circ} \mathrm{C} / \mathrm{s}$, the microstructure consists predominantly of $\mathrm{M}$, with a small fraction of bainite (Figures 6(d) and (h)).

By the obtained information from the dilatometry tests, microstructural characterization and Vickers microhardness measurements, the CCT diagrams for the two studied regions were determined. In order to evaluate the differences between the CCT diagrams of each position, the diagrams were constructed one overlapping the other (Figure 7). The determined CCT diagrams are very similar. In Table 1, an increase in $\mathrm{Si}, \mathrm{Mn}$, and B contents was observed. $\mathrm{Si}$ is an element that accelerates the beginning of ferritic transformation, thus increasing the start and end temperatures of austenite decomposition ${ }^{31}$. However, the increase in $\mathrm{Mn}$ and $\mathrm{B}$ contents causes a downward displacement of the austenite decomposition start and end temperatures, that is, these elements tend to stabilize the austenite at lower temperatures ${ }^{28,38-41}$. In this context, the combined effect of the $\mathrm{B}, \mathrm{Mn}$, and $\mathrm{Si}$ contents would be the main responsible for the behavior of the steel CCT diagrams in the different positions.

However, Figure 7 shows a tendency of the austenite decomposition temperatures of position 2 to be slightly offset down from position 1 , indicating greater hardenability for position 2. This result can lead to small microstructural differences after quenching and tempering heat treatments and, consequently, the steel mechanical properties in the different studied regions, which will be presented below.

\subsection{Microstructures}

The sample of the steel as-rolled (CMn-R) presented the microstructure consisting of ferrite and eutectoid aggregates with a slight banding in the innermost region of the pipe wall (Figures 8(a)-(b)). This banding is common in hot rolled low-alloy steels and is closely related to the combination of alloying elements microsegregation, the hot strain and the final applied cooling rate. The alloying elements (Mn, $\mathrm{Cr}, \mathrm{Si}, \mathrm{Ni}$, and others.) are added to increase the mechanical strength and toughness of low carbon steels. Previous studies have shown that $\mathrm{Mn}$ is the main alloying element responsible for the development of banding in microalloyed steels ${ }^{9,42-46}$. In fact, it can be observed in Table 1 that there is a higher concentration of $\mathrm{Mn}$ in the innermost part of the pipe wall. This certainly influences the resultant microstructures from subsequent heat treatments.

The rolled and quenched sample (CMn-Q) presented a microstructure formed by martensite, bainite and ferrite, Figure $8(\mathrm{c})$. The presence of the MA constituent was not observed. Figure 8(d) shows the microstructure of the tempered sample (CMn-QT) that exhibited a microstructure consisting of ferrite, bainite and tempering sorbite (ferrite and cementite particles). Different authors obtained similar results in their works, analyzing the microstructures after quenching and tempering of steels with similar chemical compositions to the one studied ${ }^{9,47}$.

Due to the dilatometry results it was expected to observe microstructural differences between the two studied regions. 


\section{Position 1}

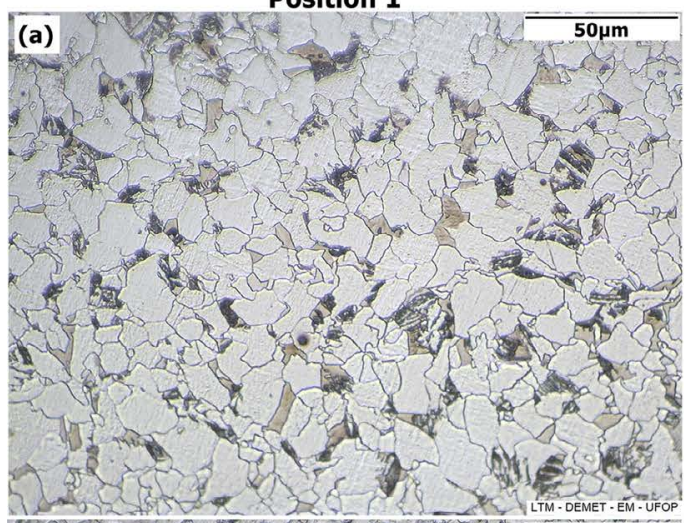

\section{Position 2}

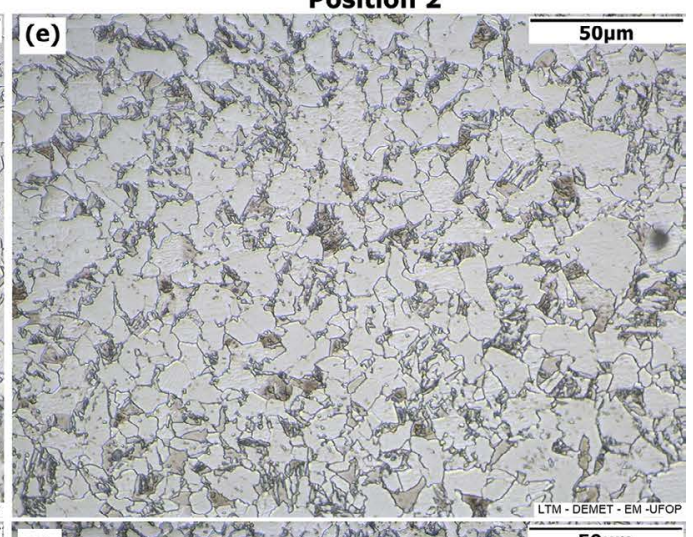

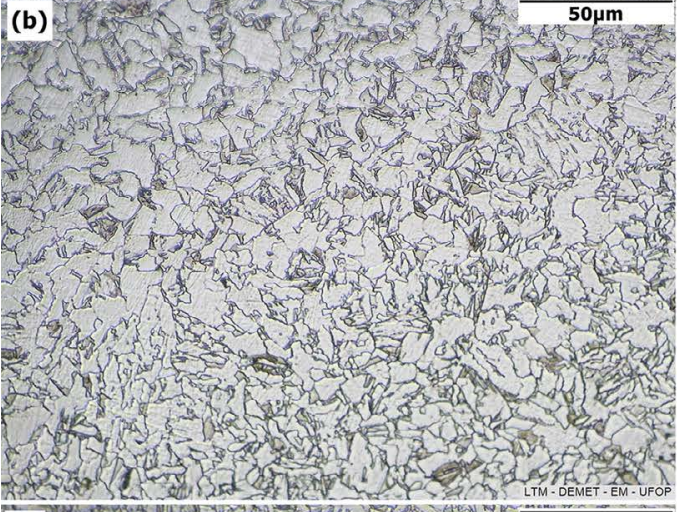
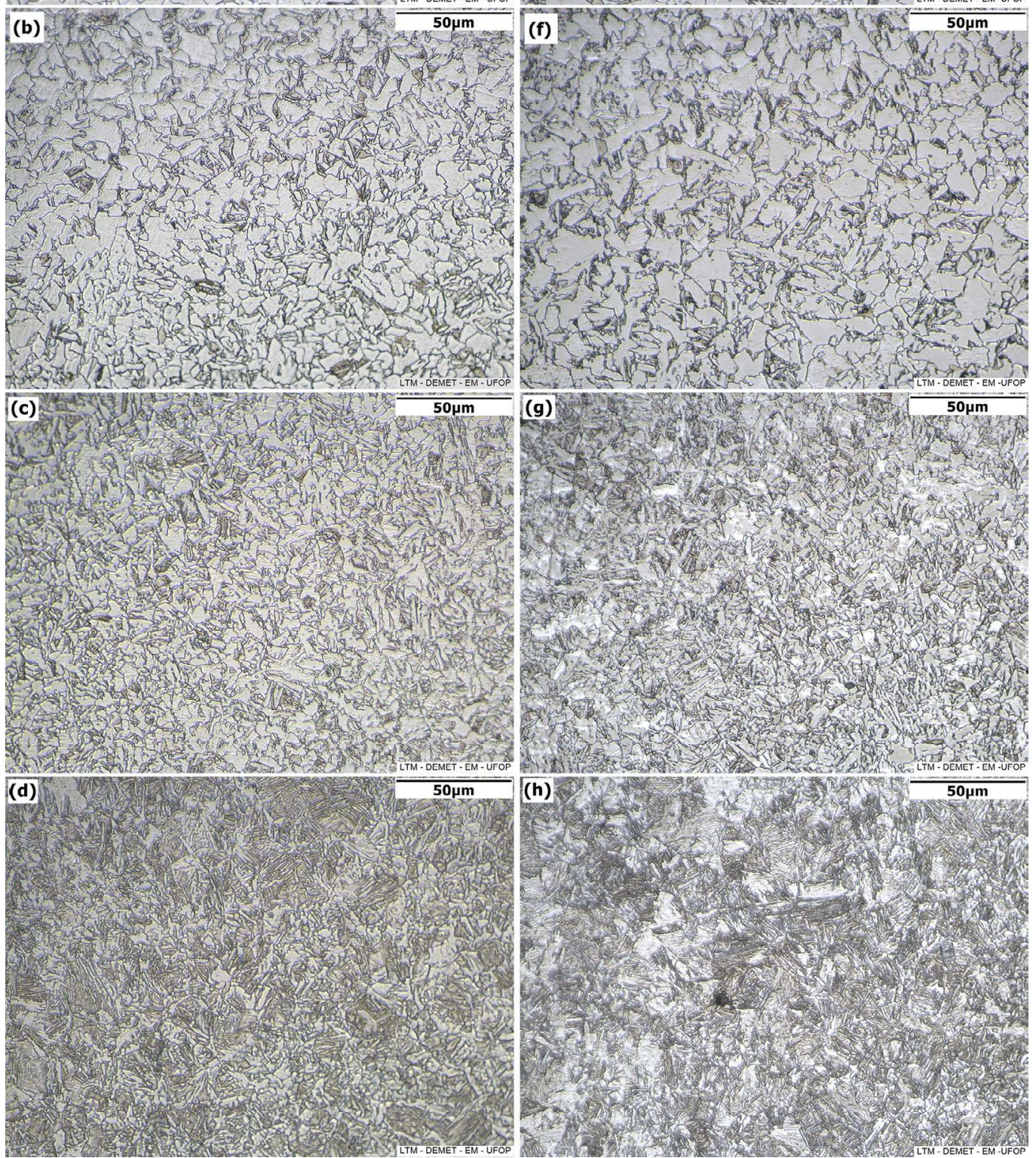

Figure 5. Optical micrographs of the dilatometry specimens of position 1 (a)-(d) and position 2 (e)-(h) austenitizing at $920^{\circ} \mathrm{C}$ and cooled to (a) and (e) $2^{\circ} \mathrm{C} / \mathrm{s}\left(\mathrm{PF}+\mathrm{P}+\mathrm{P}^{\prime}\right) ;(\mathrm{b})$ and (f) $7^{\circ} \mathrm{C} / \mathrm{s}(\mathrm{QF}+\mathrm{GF}+\mathrm{BF}) ;(\mathrm{c})$ and $(\mathrm{g}) 20^{\circ} \mathrm{C} / \mathrm{s}(\mathrm{GF}+\mathrm{BF}) ;(\mathrm{d})$ and (h) $100^{\circ} \mathrm{C} / \mathrm{s}(\mathrm{B}+\mathrm{M})$. C-Mn steel. Nital $2 \%$. 

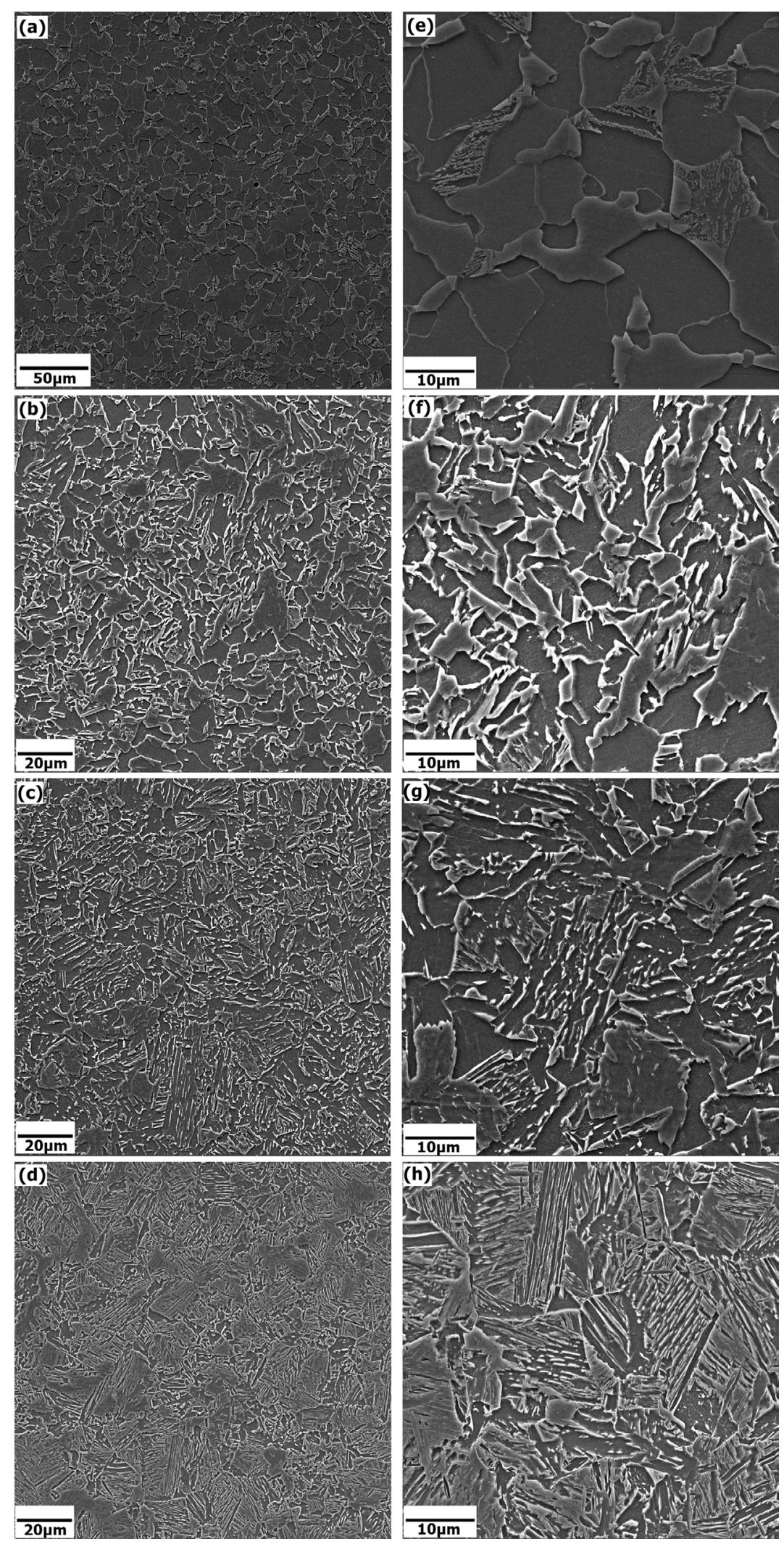

Figure 6. SEM micrographs of the dilatometry specimens of position 2 of the C-Mn steel. Nital $2 \%$. (a) and (e) $2{ }^{\circ} \mathrm{C} / \mathrm{s}\left(\mathrm{PF}+\mathrm{P}+\mathrm{P}^{\prime}\right)$; (b) and (f) $7{ }^{\circ} \mathrm{C} / \mathrm{s}(\mathrm{QF}+\mathrm{GF}+\mathrm{BF}) ;(\mathrm{c})$ and $(\mathrm{g}) 20^{\circ} \mathrm{C} / \mathrm{s}(\mathrm{GF}+\mathrm{BF})$; (d) and (h) $100^{\circ} \mathrm{C} / \mathrm{s}(\mathrm{B}+\mathrm{M})$. 
Nevertheless it is noteworthy that these differences are small and that the microstructural changes caused by the differences in chemical composition are localized and were not clearly noticed in the microstructural analyzes of the samples after the heat treatments.

The variations of chemical composition observed in Table 1 did not significantly influence the values of average prior austenitic grain size of the two studied regions. Both position presented approximately average prior austenitic grain size value equal to $23 \pm 3 \mu \mathrm{m}$.

\subsection{Vickers microhardness measurements}

Table 3 shows the Vickers microhardness results for asrolled (CMn-R), rolled and quenched (CMn-Q) and quenched and tempered (CMn-QT) steel of the two studied regions. It is observed that the CMn-Q sample presented higher microhardness values. This result can be explained by the presence of the hardening constituents on its microstructure (martensite and bainite), as seen in Figure 8(c). Comparing the CMn-R, CMn-Q and CMn-QT samples, the latter presented a decrease in microhardness in relation to the CMn-Q sample, but an increase in relation to the CMn-R sample. This reduction of microhardness in the CMn-QT sample is related to the effect of tempering that alleviates internal stresses due to the steel phase transformations. The tempering promotes several effects on the steel microstructure, starting with carbon segregation in martensite crystals followed by intermediate carbides formation and, finally cementite precipitation with martensite decomposition to ferrite. The ferrite may be recovered and recrystallized, decreasing the dislocations density in the structure ${ }^{47}$. No significant level of

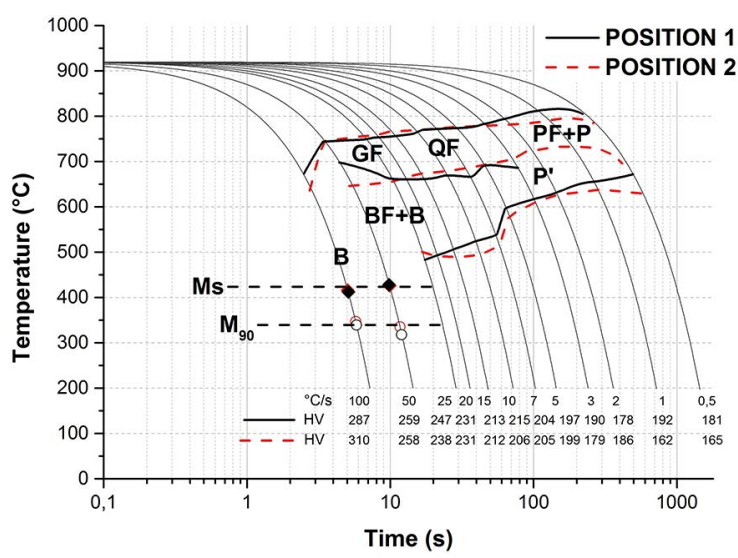

Figure 7. Comparison between CCT diagrams obtained for the $\mathrm{C}-\mathrm{Mn}$ steel in position 1 and position $2 . \mathrm{PF}=$ polygonal ferrite; $\mathrm{P}=$ perlite; $\mathrm{P}^{\prime}=$ degenerate perlite; $\mathrm{B}=$ bainite; $\mathrm{M}=$ martensite; $\mathrm{QF}=$ quasipolygonal ferrite; $\mathrm{GF}=$ granular ferrite; $\mathrm{BF}=$ bainitic ferrite.
Table 3. Vickers microhardness (HV0.20) of C-Mn steel.

\begin{tabular}{lcc}
\hline SAMPLE & POSITION & HV \\
\hline \multirow{2}{*}{ CMn-R } & 1 & $211 \pm 16$ \\
& 2 & $208 \pm 17$ \\
CMn-Q & 1 & $364 \pm 22$ \\
& 2 & $393 \pm 12$ \\
CMn-QT & 1 & $238 \pm 12$ \\
& 2 & $272 \pm 15$ \\
\hline
\end{tabular}

CMn-R: as-rolled steel; CMn-Q: rolled and quenched steel; CMn-QT: quenched and tempering steel; Position 1: outer region; Position 2: inner region.

cementite spheroidization was observed. It can be seen that after the quenching and tempering heat treatments, the steel presented in position 2 higher values of microhardness. These values can be attributed to chemical segregation (Table 1), where regions enriched with manganese originate sites of high hardenability, which can lead to the formation of high hardness constituents ${ }^{1,48}$, which were not observed by the metallographic methods employed in this work.

\subsection{Charpy impact properties}

Table 4 shows the Charpy impact results obtained in the two analyzed regions at temperatures of $-30^{\circ} \mathrm{C}$ and $-60^{\circ} \mathrm{C}$. The two positions exhibited similar behavior when tested at $-30^{\circ} \mathrm{C}$, the absorbed energy was approximately $100 \mathrm{~J}$ and $100 \%$ ductile fracture was obtained. However, at $-60^{\circ} \mathrm{C}$, position 1 presented better performance, that is, higher values of absorbed energy and higher percentage of ductile fracture compared to position 2 were verified. This result evidence that the higher content of alloying elements observed in Table 1 such as $\mathrm{Mn}$ and $\mathrm{S}$ in position 2 may contribute, in low carbon steels, to greater precipitation of sulfides, besides hardening by solid solution promoted by Mn, thus reducing its toughness ${ }^{49-51}$.

Figure 9 shows the SEM fractographies of the fracture surfaces of the positions 1 and 2 , tested at $-60^{\circ} \mathrm{C}$. In position 1 (Figure 9(a)), the steel exhibited a ductile behavior, that is, nucleation, growth and coalescence of microvoids, presenting dimples throughout the fracture surface. However, the steel in position 2 exhibited a mixture of rupture mechanisms, presenting dimples, characteristic of ductile fracture, and cleavage facets and river marks, characteristic of brittle fracture (Figure 9(b)). This result is consistent with the results presented in Table 4, since the SEM fractography exhibits dominant brittle fracture morphology, indicating low values of absorbed energy by the samples ${ }^{9}$. 


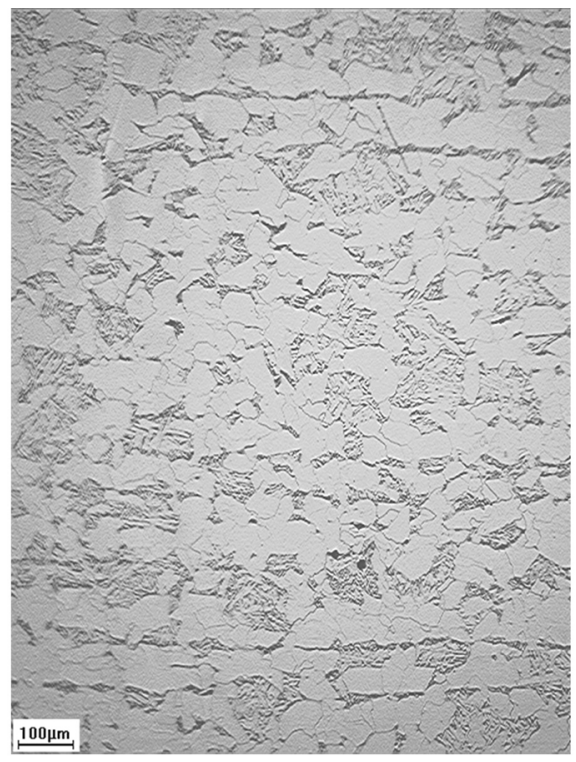

(a) CMn-R sample, OM. Ferrite (white part) and eutetoid aggregates (dark part).

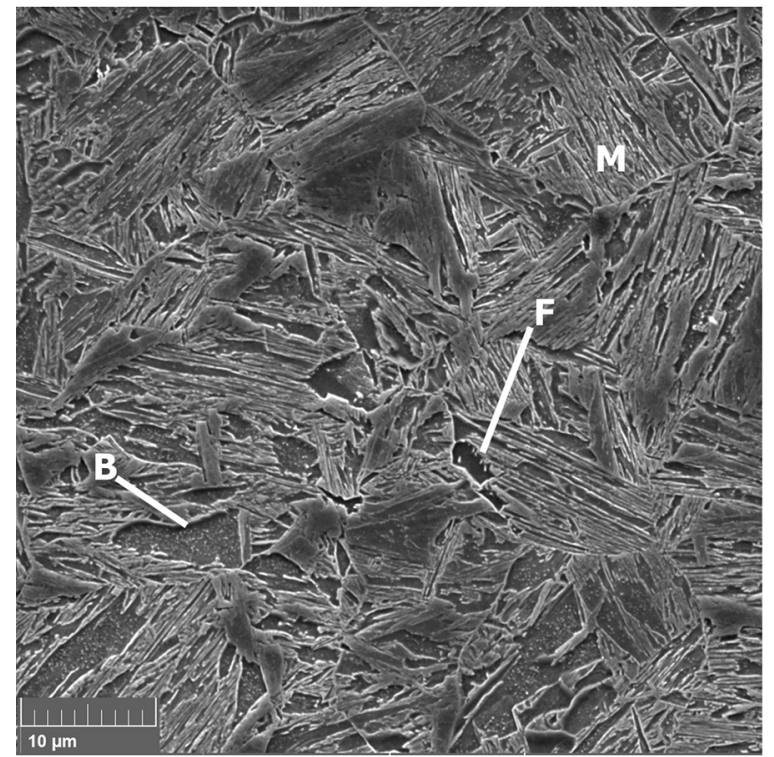

(c) CMn-Q sample, SEM.

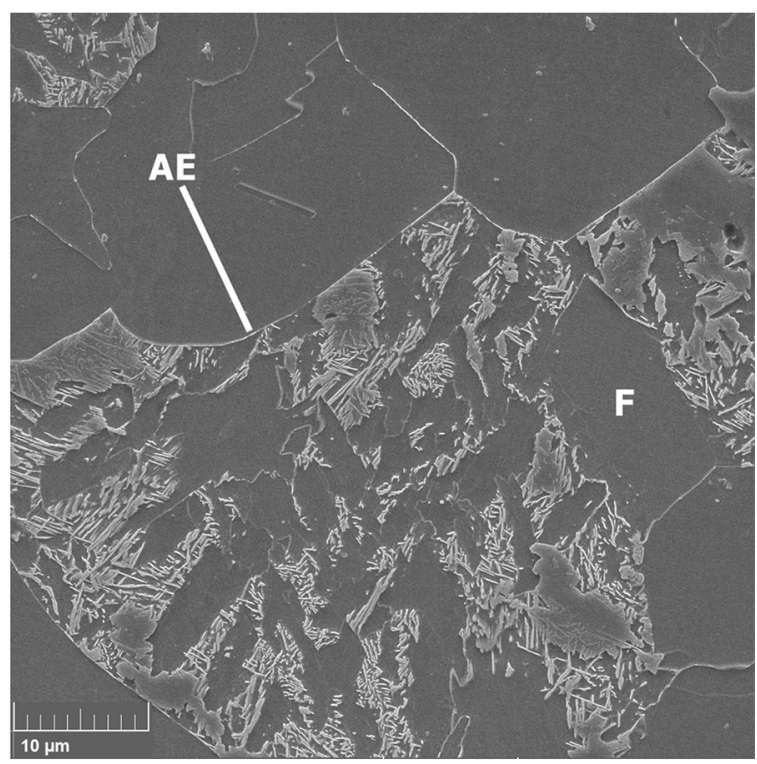

(b) CMn-R sample, SEM.

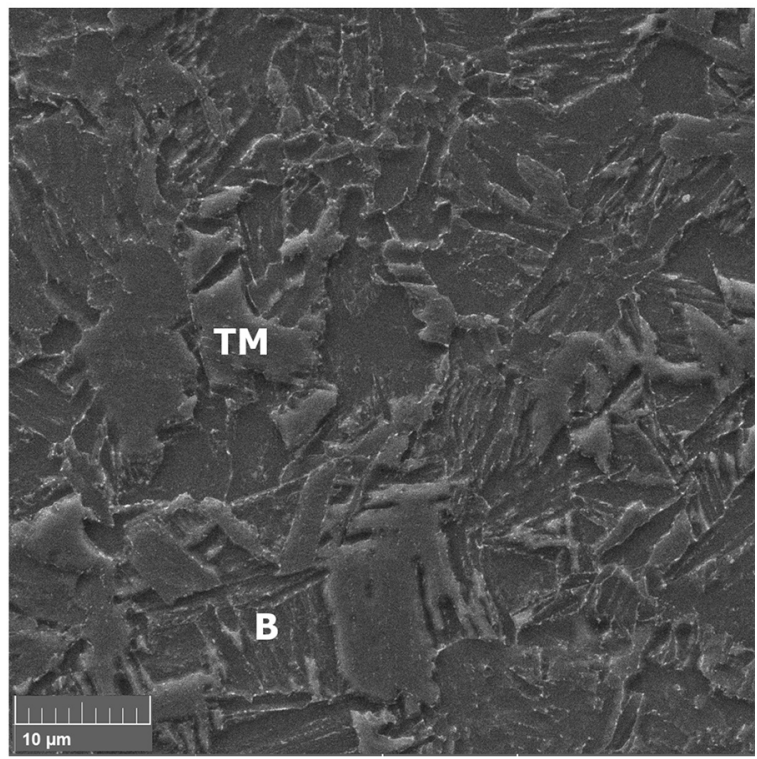

(d) CMn-QT sample, SEM.

Figure 8. $\mathrm{OM}$ and SEM micrographs. Nital $2 \%$ etching. $\mathrm{F}=$ ferrite; $\mathrm{AE}=$ eutetoid aggregates; $\mathrm{TM}=$ tempered martensite; $\mathrm{B}=$ bainite; $\mathrm{M}=$ martensite. CMn-R: as-rolled steel; CMn-Q: rolled and quenched steel; CMn-QT: quenched and tempering steel.

Table 4. Charpy impact properties of the C-Mn steel.

\begin{tabular}{cccccc}
\hline \multirow{2}{*}{ SAMPLE } & POSITION & EA (J) & \multicolumn{2}{c}{ DF (\%) } \\
& & $-30^{\circ} \mathrm{C}$ & $-60^{\circ} \mathrm{C}$ & $-30^{\circ} \mathrm{C}$ & $-60^{\circ} \mathrm{C}$ \\
\hline \multirow{2}{*}{ CMn-QT } & 1 & $98 \pm 1$ & $104 \pm 2$ & 100 & 100 \\
& 2 & $102 \pm 2$ & $77 \pm 14$ & 100 & $85 \pm 26$ \\
\hline
\end{tabular}

CMn-QT: quenched and tempered steel; AE: absorbed energy; DF: \% of ductile fracture; Position 1: outer region; Position 2: inner region. 


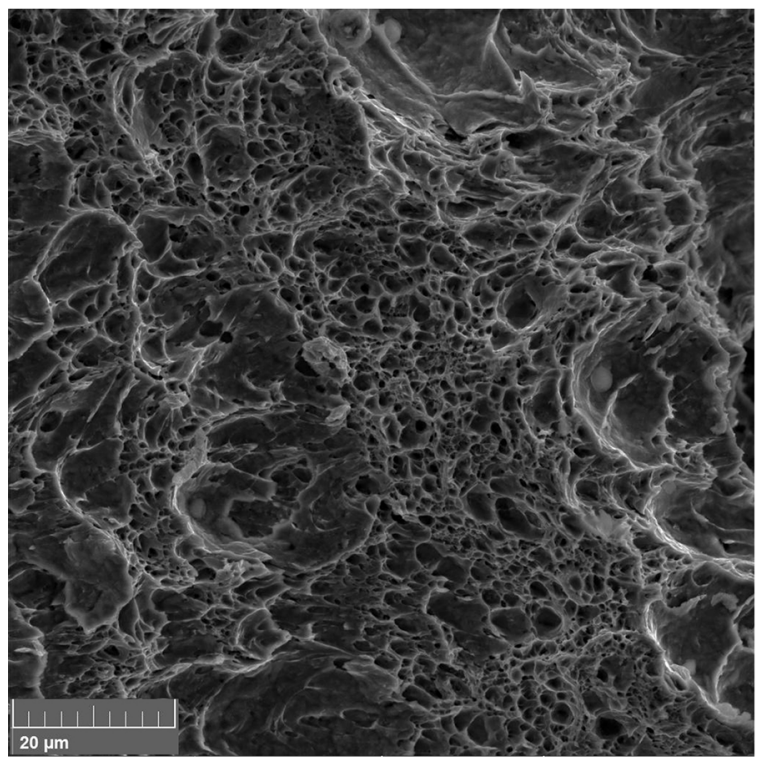

(a) Position 1.

Figure 9. SEM fractographies, Charpy impact specimens.

\section{Conclusions}

From this study, the following conclusions were obtained:

1. It was observed that there is a trend of chemical segregation from the outermost part to the innermost part of the pipe wall, especially $\mathrm{C}, \mathrm{Mn}$, $\mathrm{Si}, \mathrm{Nb}$ and $\mathrm{B}$. This may be related to the effects of chemical segregation from the solidification of the bar associated with the Mannesmann process of seamless pipe rolling.

2. The CCT diagrams for the two regions studied were constructed from the dilatometry tests, microstructural characterization and Vickers microhardness measurements. A tendency was observed for the austenite decomposition temperatures of the inner region of the pipe wall to be slightly shifted downward relative to the outer region, resulting in small microstructural differences after the quenching and tempering treatments and, consequently, the mechanical properties of the steel in the different studied regions.

3. The steel $\mathrm{Ac}_{1}$ temperatures for position 1 and position 2 were $756 \pm 7^{\circ} \mathrm{C}$ and $735 \pm 8^{\circ} \mathrm{C}$, respectively. Besides, the steel $\mathrm{Ac}_{3}$ temperatures for position 1 and position 2 were $871 \pm 6^{\circ} \mathrm{C}$ and $873 \pm 9^{\circ} \mathrm{C}$, respectively. The rate of austenite transformation was higher for position 1 as a function of the relative lower concentration of chemical elements that make carbon diffusion less difficult for the transformation to take place.

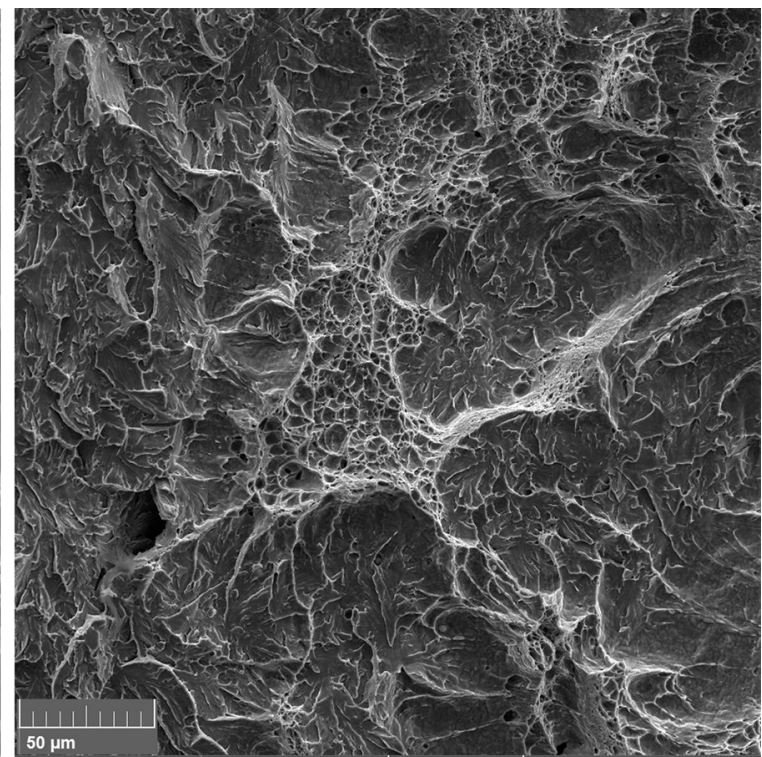

(b) Position 2.

The kinetics of austenitization of steel obey an exponential law of the JMAK model. The average values of $n$ for position 1 and position 2 were 2.09 and 2.23, respectively, and the average values of $\mathrm{k}$ were $1.79 \times 10^{-3}$ and $7.64 \times 10^{-4}$, respectively.

4. The as-rolled steel has microstructure consisting of ferrite and eutetoid aggregates with a slight banding in the innermost region of the pipe wall. After quenching heat treatment the steel shows a microstructure formed by martensite, bainite and ferrite. MA constituent have not been noticed. Subsequent to the tempering heat treatment the steel shows the microstructure consisting of ferrite, bainite, tempered martensite and carbides (cementite particles). After these heat treatments, the microstructural changes caused by differences in chemical composition were localized and were not clearly noticed in microstructural analyzes.

5. The inner region of the wall pipe presented higher microhardness values after quenching and tempering treatments and its impact toughness was slightly lower in tests at $-60^{\circ} \mathrm{C}$ compared to the outer region, corroborating with the dilatometry tests results.

\section{Acknowledgements}

The authors would like to acknowledge the Coordenação de Aperfeiçoamento de Pessoal de Nível Superior (CAPES) and Conselho Nacional de Desenvolvimento Científico e Tecnológico (CNPq) for the financial support. 


\section{References}

1. Ogata PH, Goldenstein H, Gorni AA, LandgrafFJG. Caracterização microestrutural ao longo da espessura de chapa grossa de aço microligado para tubos API 5L-X65. In: 64th ABM Annual Congress; 2009 Jul 13-17; Belo Horizonte, MG, Brazil.

2. Koshikawa T, Bellet M, Gandin CA, Yamamura H, Bobadilla M. Experimental study and two-phase numerical modeling of macrosegregation induced by solid deformation during punch pressing of solidifying steel ingots. Acta Materialia. 2017;124:513-527.

3. Ge H, Ren F, Li J, Hu Q, Xia M, Li J. Modelling of ingot size effects on macrosegregation in steel castings. Journal of Materials Processing Technology. 2018;252:362-369.

4. Ge H, Ren F, Cai D, Hao J, Li J, Li J. Gradual-cooling solidification approach to alleviate macrosegregation in large steel ingots. Journal of Materials Processing Technology. 2018;262:232-238.

5. Shin SY. Effects of Microstructure on Tensile, Charpy Impact, and Crack Tip Opening Displacement Properties of Two API X80 Pipeline Steels. Metallurgical and Materials Transactions A. 2013;44(6):2613-2624.

6. Batalha RL, Godefroid LB, Faria GL, Porcaro RR, Cândido LC, Trindade VB. Envelhecimento por Deformação em Juntas Soldadas de Tubos de Aço API 5L X65Q sem Costura. Soldagem \& Inspeção. 2015;20(3):324-332.

7. Hillenbrand HG, Kalwa C. Production and Service Behavior of High Strength Large Diameter Pipe. In: Proceedings of International Conference on Application and Evaluation of High Grade Linepipes in Hostile Environments; 2002 Nov 8-9; Yokohama, Japan. Ratingen: EUROPIPE.

8. Siciliano F, Stalheim DG, Gray JM. Modern High Strength Steels for Oil and Gas Transmission Pipelines. In: Proceedings of 7th International Pipeline Conference; 2008 Sept 29-Oct 3; Calgary, AB, Canada.

9. Godefroid LB, Sena BM, Trindade Filho VB. Evaluation of Microstructure and Mechanical Properties of Seamless Steel Pipes API 5L Type Obtained by Different Processes of Heat Treatments. Materials Research. 2017;20(2):514-522.

10. Gomez G, Pérez T, Bhadeshia HKDH. Air cooled bainitic steels for strong, seamless pipes Part 1 - alloy design, kinetics and microstructure. Materials Science and Technology. 2009;25(12):1501-1507.

11. Trindade VB, Souza EDS, de Paula JMA, Costa MCMDS, de Faria GL. Efeito de Diferentes Tratamentos Térmicos sobre Microestrutura e Microdureza de um Sistema Aço C-Mn/ Revestimento de Inconel 625. Tecnologia em Metalurgia, Materiais e Mineração. 2017;14(2):167-174.

12. American Petroleum Institute. Specification for Line Pipe. ANSI/API Specification 5L. 45th ed. Washington: American Petroleum Institute; 2012.

13. ASTM International. ASTM E92-17-Standard Test Methods for Vickers Hardness and Knoop Hardness of Metallic Materials. West Conshohocken: ASTM International; 2017.
14. de Andrés CG, Caballero FG, Capdevila C, Álvarez LF. Application of dilatometric analysis to the study of solid-solid phase transformations in steels. Materials Characterization. 2002;48(1):101-111.

15. Zhao JZ, Mesplont C, De Cooman C. Calculation of the phase transformation kinetics from a dilatation curve. Journal of Materials Processing Technology. 2002;129(1-3):345-348.

16. Lopes MMB, Cota AB. A study of isochronal austenitization kinetics in a low carbon steel. Rem: Revista Escola de Minas. 2014;67(1):61-66.

17. Pawlowski B, Bala P, Dziurka R. Improper Interpretation of Dilatometric Data for Cooling Transformation in Steels. Archives of Metallurgy and Materials. 2014;59(3):1159-1161.

18. Faria GL, Cardoso RA, Lino JJP. Efeito da Composição Química sobre a Cinética de Transformação de Fases de Aços Baixo Carbono Microligados Laminados pelo Processo Steckel. In: 54ํㅗㄹ Seminário de Laminação e Conformação; 2017 Oct 2-6; São Paulo, SP, Brazil. p. 222-235.

19. de Faria GL, de Paula JMA, de Lima MSF. Characterization of Phase Transformations and Microstructural Changes in an API 5CT L80 Steel Grade During Ni Alloy Laser Cladding. Materials Research. 2018;21(5):e20180294.

20. Johnson W, Mehl R. Reaction Kinetics in Processes of Nucleation and Growth. Transactions of the Metallurgical Society of AIME. 1939;135:416-458.

21. Avrami M. Kinetics of Phase Change. II Transformation-Time Relations for Random Distribution of Nuclei. The Journal of Chemical Physics. 1940;8(2):212-224.

22. Liu F, Yang C, Yang G, Zhou Y. Additivity rule, isothermal and non-isothermal transformations on the basis of an analytical transformation model. Acta Materialia. 2007;55(15):52555267.

23. Singh SB, Krishnan K, Sahay SS. Modeling non-isothermal austenite to ferrite transformation in low carbon steels. Materials Science and Engineering: A. 2007;445-446:310315 .

24. ASTM International. ASTM E3-11 (2017) - Standard Guide for Preparation of Metallographic Specimens. West Conshohocken: ASTM International; 2017.

25. ASTM International. ASTM E112-13 - Standard Test Methods for Determining Average Grain Size. West Conshohocken: ASTM International; 2013.

26. LePera FS. Improved Etching Technique to Emphasize Martensite and Bainite in High-Strength Dual-Phase Steel. JOM. 1980;32(3):38-39.

27. ASTM International. ASTM A370-17 - Standard Test Methods and Definitions for Mechanical Testing of Steel Products. West Conshohocken: ASTM International; 2017.

28. Krauss G. Steels: Processing, Structure, and Performance. Materials Park: ASM International; 2005.

29. Lu Y. Effect of Boron on Microstructure and Mechanical Properties of Low Carbon Microalloyed Steels. [Thesis]. Montreal: McGill University; 2007. 99 f. 
30. Suski CA, de Oliveira CAS. Effects of austenitization temperature on the microstructure of $15 \mathrm{BCr} 30$ and PL22 boron steels. Materials Research. 2013;16(4):803-810.

31. Coldren AP, Eldis GT. Using CCT Diagrams to Optimize the Composition of an As-Rolled Dual-Phase Steel. JOM. 1980;32(3):41-48.

32. Nouri A, Saghafian H, Kheirandish S. Effects of Silicon Content and Intercritical Annealing on Manganese Partitioning in Dual Phase Steels. Journal of Iron and Steel Research International. 2010;17(5):44-50.

33. Gervas'ev MA, Yurovskikh AS, Belikov SV, Maslova OV, Zhilin AS. Influence of Al and Si on austenite formation in $\mathrm{Cr}-\mathrm{Ni}$-Mo steel in the intercritical temperature range. Steel in Translation. 2015;45(9):658-661.

34. Cahn JW. The kinetics of grain boundary nucleated reactions. Acta Metallurgica. 1956;4(5):449-459.

35. Lopes MMB. Efeito da fração de martensita na cinética de formação da austenita em um aço de baixo carbono. [Dissertation]. Ouro Preto: Universidade Federal de Ouro Preto; 2012. 103 f.

36. Datta DP, Gokhale AM. Austenitization kinetics of pearlite and ferrite aggregates in a low carbon steel containing $0.15 \mathrm{wt}$ pct C. Metallurgical Transactions A. 1981;12(3):443-450.

37. Oliveira FLG, Andrade MS, Cota AB. Kinetics of austenite formation during continuous heating in a low carbon steel. Materials Characterization. 2007;58(3):256-261.

38. Maitrepierre P, Thivellier D, Tricot R. Influence of boron on the decomposition of austenite in low carbon alloyed steels. Metallurgical Transactions A. 1975;6(2):287.

39. Zhu K, Oberbillig C, Musik C, Loison D, Iung T. Effect of B and $\mathrm{B}+\mathrm{Nb}$ on the bainitic transformation in low carbon steels. Materials Science and Engineering: A. 2011;528(12):4222-4231.

40. Calcagnotto M, Ponge D, Raabe D. On the Effect of Manganese on Grain Size Stability and Hardenability in Ultrafine-Grained Ferrite/Martensite Dual-Phase Steels. Metallurgical and Materials Transactions A. 2012;43(1):37-46.
41. Terzic A, Calcagnotto M, Guk S, Schulz T, Kawalla R. Influence of Boron on transformation behavior during continuous cooling of low alloyed steels. Materials Science and Engineering: A 2013;584:32-40.

42. Thompson SW, Howell PR. Factors influencing ferrite/pearlite banding and origin of large pearlite nodules in a hypoeutectoid plate steel. Materials Science and Technology. 1992;8(9):777-784.

43. Khalid FA, Farooque M, Haq A, Khan AQ. Role of ferrite/ pearlite banded structure and segregation on mechanical properties of microalloyed hot rolled steel. Materials Science and Technology. 1999;15(10):1209-1215.

44. Verhoeven JD. A review of microsegregation induced banding phenomena in steels. Journal of Materials Engineering and Performance. 2000;9(3):286-296.

45. Krauss G. Solidification, segregation, and banding in carbon and alloy steels. Metallurgical and Materials Transactions B. 2003;34(6):781-792.

46. Krebs B, Germain L, Hazotte A, Gouné M. Banded structure in Dual Phase steels in relation with the austenite-to-ferrite transformation mechanisms. Journal of Materials Science. 2011;46(21):7026-7038.

47. Muniz TF, Trindade VB, Mendes MKO, Faria GL. Efeito de alguns tratamentos térmicos sobre a microestrutura e propriedades mecânicas de um aço microligado. In: 70th ABM Annual Congress; 2015 Ago 17-21; Rio de Janeiro, RJ, Brazil.

48. Bhadeshia HKDH. Alternatives to the Ferrite-Perlite Microstructures. Materials Science Forum. 1998;284-286:39-50.

49. Svensson LE, Gretoft B. Microstructure and Impact Toughness of C-Mn Weld Metals. Welding Research Supplement. 1990;69(12):454s-461s.

50. Magnabosco R, Rossetto LC. Toughness of two HSLA steel sheets. Journal of the Brazilian Society of Mechanical Sciences and Engineering. 2003;25(2):170-173.

51. Toffolo RVB. Estudo comparativo dos aços microligados API5L-X60 e API-5LX70, usados para confecção de tubos, quanto à tenacidade à fratura. [Dissertation]. Ouro Preto: Universidade Federal de Ouro Preto; 2008. $191 \mathrm{f}$. 